\title{
Application of the Growth Inhibition Test to Spiroplasma Taxonomy
}

\author{
R. F. WHITCOMB,${ }^{1}$ J. G. TULLY,${ }^{2}$ P. MCCAWLEY, ${ }^{1}$ AND D. L. ROSE ${ }^{2}$
}

Insect Pathology Laboratory, Plant Protection Institute, Agricultural Research Service, United States Department of Agriculture, Beltsville, Maryland $20705^{1}$ and Mycoplasma Section, Laboratory of Molecular Microbiology, National Institute of Allergy and Infectious Diseases, Frederick, Maryland 21701 2

A total of 33 triply cloned Spiroplasma strains were studied by the conventional growth inhibition test on M1A or M1D agar plates. Sera were prepared to 17 of the isolates, representing five major groups and the four subgroups (subgroups I-1, I2, I-3 and I-4) of the Spiroplasma citri complex. Zone sizes varied with the titer and the growth rate of the spiroplasma cultures used as antigens. Test results were standardized by recording zone widths that developed on plates inoculated with cultures containing about $0^{5}$ colony-forming units per $\mathrm{ml}$. Zone widths in homologous tests ranged from 5 to $19 \mathrm{~mm}$, but were usually at least $10 \mathrm{~mm}$ for all but the fastest growing spir-plasmas. Nonspecific zones 1 to $4 \mathrm{~mm}$ in width were observed rarely in heterologous crosses between major serogroups, but were characteristic of certain individual strain-antibody combinations and were not observed when other strains of the group or subgroup were examined. Heterologous reactions resulting in zones 2 to $15 \mathrm{~mm}$ wide among the four subgroups of the $S$. citri complex (group I) were observed; such partial reactions were characteristic of all strains within each subgroup. Deoxyribonucleic acid hybridization experiments have shown that major Spiroplasma groups are distinct and can be considered to be putative species. Therefore, growth inhibition serology apparently functions in the Spiroplasmataceae as a test applicable for differentiation at the species level, as it does in the Mycoplasmataceae.

At its meeting in Glasgow in 1976, the Subcommittee on Taxonomy of Mollicutes initiated (43) an ad hoc working group to delineate characters suitable for differentiating and classifying strains of the genus Spiroplasma. Some of the work of this team, especially that concerning one-dimensional gel electrophoresis (14) and two-dimensional gel electrophoresis $(31,32)$, has been published. Work involving the spiroplasma genome, including an analysis of the guanineplus-cytosine contents of isolates and deoxyribonucleic acid (DNA)-DNA homologies, has also been completed $(3,4,25)$. Since the 1976 meeting, spiroplasma isolates have accumulated rapidly, and the need for adequate serological methods for the identification and classification of these isolates is more pressing today than ever.

The growth inhibition (GI) test has been employed regularly for the classification of mycoplasmas at the species level $(13,58)$. This test has also been applied, with limited scope, to differentiation of strains of the genus Spiroplas$m a(6,15-19,36,39,41,44-49,51,54)$. The GI test and modifications of it are a result of the original observations of Nicol and Edward (33) and Edward and Fitzgerald (21) that antisera, when incorporated into the growth media of mycoplasmas, inhibited not only the growth of the mycoplasma against which the serum was directed but also that of closely related strains. This concept was adapted by Huijmans-Evers and Ruys in 1956 (22) and modified in detail by Clyde (13). In Clyde's modified procedure, serum-saturated disks were placed on the surfaces of inoculated agar plates. Today, the disk modification of the GI test is the most commonly employed serological method for separation of Mycoplasma species (42).

In this study, we examined 33 triply cloned Spiroplasma strains and sera prepared to 17 of the strains to assess the resolution provided by application of the disk GI test to questions of Spiroplasma taxonomy.

\section{MATERIALS AND METHODS}

Spiroplasma strains and culture conditions. Spiroplasma strains (Table 1) were obtained from various sources. Many of the strains chosen were used in the deformation and metabolism inhibition tests previously reported $(55,57)$. Classical strains (subgroup I-1) of Spiroplasma citri (strains R8A2 [= Maroc] and C189) were taken from freeze-dried samples held as vouch- 
TABLE 1. Spiroplasma strains studied

\begin{tabular}{|c|c|c|c|c|}
\hline Group & $\begin{array}{l}\text { Scientific or common } \\
\text { name }\end{array}$ & Isolate & $\begin{array}{l}\text { ATCC } \\
\text { no. }^{a}\end{array}$ & Source \\
\hline I-1 & S. citri & $\begin{array}{l}\text { Maroc (= R8A2) } \\
\text { C189 } \\
\text { Israel } \\
\text { Cactus } \\
\text { Lettuce } \\
\text { Scaph } \\
\text { SCC } \\
\text { Algeria } \\
\text { L-163 } \\
\text { Iran }\end{array}$ & $\begin{array}{l}27556 \\
27665 \\
29594 \\
29747\end{array}$ & $\begin{array}{l}\text { Citrus (Morocco) } \\
\text { Citrus (California) } \\
\text { Citrus (Israel) } \\
\text { Opuntia (?) } \\
\text { Lettuce (?) } \\
\text { Scaphytopius leafhoppers (California) } \\
\text { Circulifer leafhoppers (California) } \\
\text { Citrus (Algeria) } \\
\text { Citrus (California) } \\
\text { Citrus (Iran) }\end{array}$ \\
\hline $\mathbf{I}-2$ & $\begin{array}{l}\text { Honey bee } \\
\text { spiroplasma }\end{array}$ & $\begin{array}{l}\text { BC-3 } \\
\text { AS } 576 \\
\text { KC-3 } \\
\text { G-1 } \\
\text { G-13 } \\
\text { Riv }\end{array}$ & $\begin{array}{l}33219 \\
29416\end{array}$ & $\begin{array}{l}\text { Honey bee (Maryland) } \\
\text { Honey bee (Maryland) } \\
\text { Honey bee (Hawaii) } \\
\text { Flower (Florida) } \\
\text { Honey bee (Florida) } \\
\text { Flower (Maryland) }\end{array}$ \\
\hline $\mathbf{I}-\mathbf{3}$ & $\begin{array}{l}\text { Corn stunt } \\
\text { spiroplasma }\end{array}$ & $\begin{array}{l}\text { E275 } \\
\text { Miss E } \\
\text { B655 } \\
\text { I-747 }\end{array}$ & $\begin{array}{l}29320 \\
\\
33289 \\
29051\end{array}$ & $\begin{array}{l}\text { Maize (Drosophila) } \\
\text { Maize (Mississippi) } \\
\text { Maize (Jamaica) } \\
\text { Maize (laboratory) }\end{array}$ \\
\hline $\mathrm{I}-4$ & 277F spiroplasma & $277 F$ & 29761 & Rabbit tick (Montana) \\
\hline III & S. floricola & $\begin{array}{l}23-6 \\
\text { OBMG } \\
\text { BNR1 }\end{array}$ & $\begin{array}{l}29989 \\
33221 \\
33220\end{array}$ & $\begin{array}{l}\text { Flowers (Maryland) } \\
\text { Flowers (Maryland) } \\
\text { Flowers (Maryland) }\end{array}$ \\
\hline IV & "Flower" spiroplasmas & $\begin{array}{l}\text { SR } 3 \\
\text { L-89 } \\
\text { PPS1 } \\
\text { B-13 } \\
\text { F-1 } \\
\text { F-2 } \\
\text { F-25 }\end{array}$ & $\begin{array}{l}33095 \\
33450\end{array}$ & $\begin{array}{l}\text { Flowers (Maryland) } \\
\text { Spittlebug (Corsica) } \\
\text { Flowers (Florida) } \\
\text { Honey bee (Morocco) } \\
\text { Flowers (France) } \\
\text { Flowers (France) } \\
\text { Flowers (Corsica) }\end{array}$ \\
\hline V & S. mirum & $\begin{array}{l}\text { SMCA } \\
\text { GT-48 } \\
\text { TP-2 }\end{array}$ & $\begin{array}{l}29335 \\
29334 \\
33503\end{array}$ & $\begin{array}{l}\text { Rabbit tick (Georgia) } \\
\text { Rabbit tick (Georgia) } \\
\text { Rabbit tick (Maryland) }\end{array}$ \\
\hline
\end{tabular}

${ }^{a}$ ATCC, American Type Culture Collection, Rockville, Md.

TABLE 2. Reciprocal GI tests with antigens and antisera of group I strains

\begin{tabular}{|c|c|c|c|c|c|c|c|c|c|c|c|}
\hline \multicolumn{2}{|c|}{ Antiserum } & \multicolumn{10}{|c|}{ Antigen } \\
\hline \multirow{2}{*}{ Subgroup } & \multirow{2}{*}{ Strain } & \multicolumn{10}{|c|}{ Subgroup I-1 (citrus stubborn spiroplasma) } \\
\hline & & Maroc & C189 & Israel & Cactus & Lettuce & Scaph & SCC & Algeria & L-163 & Iran \\
\hline \multirow[t]{5}{*}{$\mathrm{I}-1$} & Maroc & $16^{a}$ & 15 & 7 & 16 & 16 & 13 & 16 & 11 & 13 & 15 \\
\hline & $\mathrm{C} 189$ & 12 & 12 & 10 & 13 & 12 & 7 & 14 & 9 & 11 & 14 \\
\hline & Israel & 14 & 11 & 7 & 12 & 12 & 12 & 13 & 11 & 14 & 18 \\
\hline & Cactus & 17 & 17 & 9 & 11 & 17 & 14 & 15 & 10 & 12 & 20 \\
\hline & Lettuce & 16 & 17 & 11 & 16 & 17 & 15 & 16 & 10 & 13 & 15 \\
\hline I-2 & BC-3 & 12 & 12 & 10 & 10 & 11 & 13 & 15 & 10 & 13 & 12 \\
\hline \multirow[t]{2}{*}{ I-3 } & E275 & 12 & 11 & 5 & 10 & 10 & 7 & 11 & 6 & 6 & 12 \\
\hline & Miss E & 11 & 11 & 5 & 11 & 10 & 9 & 11 & 7 & 10 & 16 \\
\hline $\mathrm{I}-4$ & $277 \mathrm{~F}$ & 3 & 3 & 1 & 2 & 3 & 0 & 0 & 0 & 0 & 0 \\
\hline
\end{tabular}

\footnotetext{
${ }^{a}$ Width (in millimeters) of zone of inhibition, measured from the edge of the disk.
} 
ers from an earlier study (37). Eight other subgroup I-1 strains were utilized. The triply cloned Israel strain was derived from a strain that was furnished by $\mathbf{M}$. Daniels et al. from their studies (29) and that had been triply cloned and freeze-dried in the Beltsville laboratory. "Cactus" and "lettuce" spiroplasmas, which were claimed to have been isolated from Opuntia tuna subsp. monstrosa (F. Kondo, A. H. McIntosh, S. B. Padhi, and K. Maramorosch, Proc. Soc. Gen. Microbiol. 3:154, 1976) and commercial lettuce (8), respectively, were derived from ATCC 29594 and ATCC 29747 cultures. The Scaph, SCC, Algeria, and Iran strains were obtained from the collection of P. H. M. Saglio; strain L-163 was obtained from A. Granett. These five strains were triply cloned in Beltsville. The BC-3 and KC-3 strains of honey bee spiroplasma (subgroup I-2) were obtained from lines studied (10, 11) by T. B. Clark. The AS 576, G-1, G-13, and BW strains of subgroup I-2 were obtained from R. E. Davis. The E275 and Miss E strains of subgroup I-3 corn stunt spiroplasma were derived from lines maintained in previous studies $(24,56)$. The B655 isolate (Jamaica) of corn stunt spiroplasma (20) was triply cloned and preserved in the Beltsville laboratory after receipt as an uncloned isolate from $\mathrm{S}$. Eden-Green. The single subgroup I-4 strain, $277 \mathrm{~F}$ spiroplasma (5, $34,39)$ from W. Burgdorfer, was triply cloned and preserved at the Bethesda laboratory. The type strain (strain 23-6) of Spiroplasma floricola (group III) (18) was furnished by R. E. Davis. The OBMG and BNR1 strains of $S$. floricola were furnished by T. B. Clark from his studies (11). Seven representatives of group IV spiroplasmas were used. The SR 3 strain was obtained from R. E. Davis, and the PPS1 strain was obtained from R. E. McCoy. The L-89, B-13, F-1, F-2, and F-25 strains were derived from field isolates obtained in the Mediterranean region (50), but were later studied (44) and preserved in the Bethesda laboratory. The SMCA and GT-48 strains of Spiroplasma mirum (48) (group V) were from the Bethesda laboratory $(47,49)$, whereas the TP-2 strain (41) was cloned and preserved in the Beltsville laboratory.

Group V strains were maintained in and plated onto SP-4 medium (47). All other Spiroplasma isolates were maintained in and plated onto M1D medium; in this variation of M1A medium (24), the fresh yeast extract component was replaced by sterile water.

Disk GI method. Liquid and solid media were prepared as previously reported. Cultures growing in SP-4 or M1D medium were diluted in 10 -fold steps. Four dilutions were selected that were expected to optimize the chance of including at least one dilution that yielded about $10^{5}$ colony-forming units per $\mathrm{ml}$. In many cases, cultures were examined by dark-field microscopy, and preliminary counts of numbers of helical organisms per field were used to estimate the probable numbers of viable spiroplasma cells in the cultures (53). Samples $(0.1 \mathrm{ml})$ of each of the four dilutions were plated onto $15-\mathrm{cm}$ plates. A bent glass stirring rod was used to distribute the inoculum evenly on the plates. The inoculated plates were then allowed to stand for about $30 \mathrm{~min}$ at room temperature in a laminar flow hood. The antiserum-saturated disks were then placed on the surface of the agar at the center of the dried inoculated plates. The disks were saturated beforehand with $0.025 \mathrm{ml}$ of antiserum dispensed with a calibrated micropipette. After preparation, the disks were held at $4^{\circ} \mathrm{C}$ and could be stored for as long as several months (40).

Most plates were incubated at $30^{\circ} \mathrm{C}$, but plates inoculated with group $\mathrm{V}$ or subgroup I-4 spiroplasmas were incubated at $37^{\circ} \mathrm{C}$, and plates inoculated with $S$. citri were held at $32^{\circ} \mathrm{C}$. Plates inoculated with spiroplasmas from subgroups I-2 and I-4, and groups III and IV were incubated aerobically. Plates inoculated with other spiroplasmas were incubated in a mixture containing $95 \% \mathrm{~N}_{2}$ and $5 \% \mathrm{CO}_{2}$.

Zones were measured after appropriate incubation times, which varied with each Spiroplasma strain. For example, group III and group IV strains formed colonies rapidly, and the reactions of these strains could be read within 7 days. On the other hand, group V strains and the B655 strain of subgroup I-3 grew much more slowly, and these strains were incubated for at least 3 weeks before reading. Colony morphology varied with each strain. Strains that grew poorly tended to form discrete colonies, whereas strains that grew rapidly during the logarithmic growth phase, producing short helical cells with only a few turns, tended to form diffuse colonies with indistinct boundaries.

TABLE 2-Continued

\begin{tabular}{|c|c|c|c|c|c|c|c|c|c|c|}
\hline \multicolumn{11}{|c|}{ Antigen } \\
\hline \multicolumn{6}{|c|}{ Subgroup I-2 (honey bee spiroplasma) } & \multicolumn{4}{|c|}{ Subgroup I-3 (corn stunt spiroplasma) } & \multirow{2}{*}{$\begin{array}{l}\text { Subgroup I-4 } \\
\text { (277F } \\
\text { spiroplasma) }\end{array}$} \\
\hline BC-3 & AS 576 & $\mathrm{KC}-3$ & G-1 & G-13 & BW & E275 & Miss E & $1-747$ & B655 & \\
\hline 10 & 6 & 7 & 9 & 6 & 5 & 9 & 8 & 13 & 15 & 1 \\
\hline 8 & 5 & 6 & 6 & 5 & 6 & 8 & 9 & 8 & 14 & 1 \\
\hline 9 & 6 & 7 & 7 & 5 & 5 & 13 & 4 & 12 & 13 & 0 \\
\hline 9 & 6 & 8 & 8 & 7 & 7 & 8 & 9 & 16 & 13 & 1 \\
\hline 9 & 7 & 9 & 9 & 7 & 6 & 8 & 7 & 13 & 15 & 1 \\
\hline 12 & 7 & 9 & 8 & 9 & 8 & 12 & 12 & 20 & 18 & 2 \\
\hline 4 & 5 & 2 & 3 & 2 & 0 & 18 & 18 & 21 & 19 & 9 \\
\hline 4 & 4 & 5 & 5 & 4 & 4 & 16 & 16 & 20 & 20 & 8 \\
\hline 0 & 0 & 0 & 0 & 0 & 0 & 3 & 3 & 8 & 3 & 14 \\
\hline
\end{tabular}


TABLE 3. Reciprocal GI tests with antigens and antisera of group III, IV, and V spiroplasmas

\begin{tabular}{|c|c|c|c|c|c|c|c|c|c|c|c|c|c|c|}
\hline \multicolumn{2}{|c|}{ Antiserum } & \multicolumn{13}{|c|}{ Antigen } \\
\hline \multirow{2}{*}{ Group } & \multirow{2}{*}{ Strain } & \multicolumn{3}{|c|}{ Group III (S. floricola) } & \multicolumn{7}{|c|}{ Group IV } & \multicolumn{3}{|c|}{ Group V ( $S$. mirum $)$} \\
\hline & & $23-6$ & BNR1 & OBMG & SR 3 & L-89 & PPS1 & $\mathrm{B}-13$ & F-1 & $\mathrm{F}-2$ & F-25 & SMCA & GT-48 & TP-2 \\
\hline \multirow[t]{2}{*}{ III } & BNR1 & $5^{a}$ & 5 & 5 & 0 & 0 & $\mathbf{0}$ & 0 & 0 & $\mathbf{0}$ & 0 & 0 & 0 & 0 \\
\hline & OBMG & 6 & 6 & 6 & 0 & 0 & 0 & 0 & 0 & 0 & 0 & 0 & 0 & 0 \\
\hline \multirow[t]{3}{*}{ IV } & SR 3 & 0 & $\mathbf{0}$ & 0 & 5 & 4 & 3 & 5 & 6 & 4 & 6 & 0 & 0 & 0 \\
\hline & PPS1 & 0 & 0 & 0 & 5 & 5 & 6 & 5 & 7 & 5 & 7 & $\mathbf{0}$ & 0 & 0 \\
\hline & L-89 & 0 & $\mathbf{0}$ & 0 & 7 & 6 & 5 & 5 & 9 & 4 & 6 & 0 & 0 & 0 \\
\hline \multirow[t]{3}{*}{ V } & SMCA & 0 & 0 & 0 & 0 & 0 & 0 & 0 & 0 & 0 & 0 & 13 & 15 & 15 \\
\hline & GT-48 & 0 & 0 & 0 & 0 & 0 & 0 & 0 & 0 & 0 & 0 & 13 & 17 & 12 \\
\hline & TP-2 & 0 & 0 & 0 & 0 & 0 & 0 & 0 & 0 & 0 & 0 & 9 & 17 & 10 \\
\hline
\end{tabular}

${ }^{a}$ Width (in millimeters) of zone of inhibition, measured from the edge of the disk.

TABLE 4. GI tests with antisera to group III, IV, and V spiroplasmas tested against group I antigens

\begin{tabular}{|c|c|c|c|c|c|c|c|c|c|c|c|c|c|c|}
\hline \multicolumn{2}{|c|}{ Antiserum } & \multicolumn{13}{|c|}{ Antigen } \\
\hline \multirow{2}{*}{ Subgroup } & \multirow{2}{*}{ Strain } & \multicolumn{3}{|c|}{ Group III (S. floricola) } & \multicolumn{7}{|c|}{ Group IV } & \multicolumn{3}{|c|}{ Group V (S. mirum) } \\
\hline & & $23-6$ & OBMG & BNR1 & SR 3 & L-89 & PPS1 & B-13 & F-1 & F-2 & F-25 & SMCA & GT-48 & TP-2 \\
\hline \multirow[t]{5}{*}{$\mathrm{I}-1$} & Maroc & $0^{a}$ & 0 & 0 & 0 & 0 & 0 & 0 & 0 & 0 & 0 & 0 & 0 & 0 \\
\hline & C189 & 0 & 0 & 0 & $\mathbf{0}$ & 0 & 0 & $\mathbf{0}$ & 0 & $\mathbf{0}$ & 0 & $\mathbf{0}$ & 0 & $\mathbf{0}$ \\
\hline & Israel & 0 & 0 & 0 & 0 & 0 & 0 & 0 & 0 & 0 & 0 & 0 & 0 & 0 \\
\hline & Cactus & 0 & $\mathbf{0}$ & 0 & 0 & 0 & 0 & 0 & 0 & $\mathbf{0}$ & 0 & 0 & 0 & 0 \\
\hline & Lettuce & $\mathbf{0}$ & 0 & 0 & 0 & 0 & 0 & 0 & 0 & 0 & 0 & 0 & 0 & 0 \\
\hline I-2 & BC-3 & 0 & 0 & 0 & 0 & 0 & 0 & 0 & 0 & 0 & 0 & 0 & 0 & 0 \\
\hline \multirow[t]{2}{*}{ I-3 } & E275 & 0 & 0 & 0 & 0 & 1.5 & 0 & 0 & 0 & 0 & 0 & 0 & 0 & 0 \\
\hline & Miss E & 0 & 0 & 0 & 0 & 0 & 0 & 0 & 0 & 0 & 0 & 0 & 0 & 0 \\
\hline$I-4$ & $277 \mathrm{~F}$ & 0 & 0 & 0 & 0 & 0 & 0 & 0 & 0 & 0 & 0 & 0 & 0 & 0 \\
\hline
\end{tabular}

${ }^{a}$ Width (in millimeters) of zone of inhibition, measured from the edge of the disk.

TABLE 5. GI tests with group I antigens tested against antisera of group III, IV, and V spiroplasmas

\begin{tabular}{|c|c|c|c|c|c|c|c|c|c|c|c|}
\hline \multicolumn{2}{|c|}{ Antiserum } & \multicolumn{10}{|c|}{ Antigen } \\
\hline \multirow{2}{*}{ Group } & \multirow{2}{*}{ Strain } & \multicolumn{10}{|c|}{ Subgroup I-1 (citrus stubborn spiroplasma) } \\
\hline & & Maroc & C189 & Israel & Cactus & Lettuce & Scaph & SCC & Algeria & L-163 & Iran \\
\hline \multirow[t]{2}{*}{ III } & BNR1 & $0^{a}$ & $\mathbf{0}$ & $\mathbf{0}$ & 0 & $\mathbf{0}$ & $\mathbf{0}$ & 0 & 0 & $\mathbf{0}$ & 0 \\
\hline & OBMG & 0 & 0 & $\mathbf{0}$ & 0 & $\mathbf{0}$ & 0 & 0 & 0 & 0 & $\mathbf{0}$ \\
\hline \multirow[t]{3}{*}{ IV } & SR 3 & 0 & 0 & 0 & 0 & 0 & 0 & 0 & 0 & 0 & 2 \\
\hline & PPS1 & 0 & 0 & 0 & 0 & 0 & 0 & 0 & 0 & 0 & 2 \\
\hline & L-89 & 0 & 0 & 0 & 0 & $\mathbf{0}$ & 0 & 0 & 0 & 0 & 0 \\
\hline \multirow[t]{3}{*}{ V } & SMCA & 0 & 0 & 0 & 0 & 0 & 0 & 4 & 0 & 4 & 1 \\
\hline & GT-48 & 0 & 0 & 0 & 0 & 0 & 2 & 0 & 0 & 0 & 0 \\
\hline & TP-2 & 0 & 0 & 0 & 0 & 0 & 0 & 0 & 0 & 0 & 0 \\
\hline
\end{tabular}

${ }^{a}$ Width (in millimeters) of zone of inhibition, measured from the edge of the disk. 


\section{RESULTS}

Although colonial morphology varied, homologous sera invariably produced discrete zones of inhibition. Homologous zones (Tables 2 and 3) varied in width from 5 or 6 to $18 \mathrm{~mm}$, depending on the strain, and, to a lesser extent, on the potency of the specific antiserum. For example, most group III and IV strains grew very rapidly, with colonies apparent within 3 days; such fast growth corresponds to doubling times of about $2 \mathrm{~h}$ in liquid media (R. F. Whitcomb and M. E. Coan, Abstr. Annu. Meet. Am. Soc. Microbiol. 1980, G18 p. 79). With these strains, homologous GI zones were only 5 to 6 $\mathrm{mm}$ in diameter. On the other hand, homologous zones up to $18 \mathrm{~mm}$ wide were obtained with spiroplasma strains that grew especially slowly, such as all group $\mathrm{V}$ strains and the $\mathrm{B}^{-r} 5$ strain of subgroup I-3.

None of the strains of the groups (S. citri) complex crossed significantly with strains of any other group (Tables 4 and 5). On the other hand, discrete zones, which were smaller than their homologous counterparts, were consistently observed in heterologous crosses within the group I complex (Table 2). It was not surprising to find such less intense heterologous crossing, because the members of this group have been shown to possess varying degrees of interrelatedness as determined by DNA-DNA homology $(3,4,7,25$, $26,28,35)$ and polyacrylamide gel electrophoresis $(14,31,32)$. Heterogeneity in intragroup crossing within group IV was less apparent (Table 3).

The heterologous reactions within the group I complex followed the general patterns that were expected from results involving DNA-DNA homology. Mean zone widths were computed from the reaction grids within each serological subgroup of group I and were used as rough estimates of homologous serological cross-reactivities. For example, the 50 cross-reactions of $S$. citri strains versus $S$. citri antisera gave a mean zone width of $13.3 \mathrm{~mm}$. These means could then be used to construct a table of relative crossreactivity (Table 6). It is clear from a comparison of the data from GI zones and DNA-DNA homology data $(3,4,7,25,26,28,35)$ that to a large extent, GI patterns parallel patterns in DNA-DNA homology among the subgroups.

Zones were rarely observed in heterologous crosses between groups (Tables 3 through 5). Although such zones could be obtained repeatedly with individual serum-strain combinations, they were not characteristic of all strains within each group and hence can be considered to be nonspecific.

\section{DISCUSSION}

In the genus Mycoplasma, cross-reactivity in the GI test (expressed as zones greater than 4 $\mathrm{mm}$ wide) is construed as evidence that two isolates are members of the same species. The applicability of this principle to spiroplasmas has recently been questioned (16), especially in reference to the four subgroups of the group I complex. However, the honey bee (subgroup I2) and corn stunt (subgroup I-3) spiroplasmas show high levels of DNA-DNA homology, as measured by various methods $(3,4,25,26)$. In light of data from studies of the spiroplasma genome, the Subcommittee on Taxonomy of Mollicutes recommended at the meeting in Custer, South Dakota, in 1980 (manuscript in preparation) that species designations be postponed for members of group I isolates. Actually, the degree of DNA-DNA homology (21\%) between the 277F spiroplasma (subgroup I-4) and $S$. citri (2) is considerably less than values that have conventionally been considered to be required for species distinction (23). If no intergrading members of group I existed, a case for recognition of subgroup I-4 as a species might be reasonable. Evidence of such intergrading first came when it was revealed that subgroups I-3 and I-4 showed significant crossing in deforma-

TABLE 5-Continued

\begin{tabular}{|c|c|c|c|c|c|c|c|c|c|c|}
\hline \multicolumn{11}{|c|}{ Antigen } \\
\hline \multicolumn{6}{|c|}{ Subgroup I-2 (honey bee spiroplasma) } & \multicolumn{4}{|c|}{ Subgroup I-3 (corn stunt spiroplasma) } & \multirow{2}{*}{$\begin{array}{l}\text { Subgroup I-4 } \\
\text { (277F } \\
\text { spiroplasma) }\end{array}$} \\
\hline BC-3 & AS 576 & $\mathbf{K C}-3$ & G-1 & G-13 & BW & E275 & Miss E & I-747 & B655 & \\
\hline 0 & 0 & 0 & 0 & 0 & 0 & 0 & 0 & 0 & 0 & 0 \\
\hline $\mathbf{0}$ & 0 & 0 & 0 & 0 & 0 & 0 & $\mathbf{0}$ & 0 & 0 & 0 \\
\hline 0 & 0 & 0 & 0 & 0 & 0 & 0 & 0 & 0 & 0 & 0 \\
\hline 0 & 0 & 0 & 2 & 2 & 3 & 0 & 0 & 0 & 0 & 0 \\
\hline 0 & 0 & 0 & 0 & 0 & 0 & 0 & 0 & 0 & 0 & 0 \\
\hline 1 & 0 & 0 & 0 & 0 & 0 & 0 & 0 & 0 & 0 & 0 \\
\hline 0 & 0 & 0 & 0 & 0 & 0 & 0 & 0 & 2 & 0 & 1 \\
\hline 0 & 0 & 0 & 0 & 0 & 0 & 0 & 0 & 0 & 0 & 0 \\
\hline
\end{tabular}

${ }^{a}$ Width (in millimeters) of zone of inhibition, measured from the edge of the disk. 
TABLE 6. Relative zone widths obtained with reciprocal GI tests with group I strains ${ }^{a}$

\begin{tabular}{ccccc}
\hline \multirow{2}{*}{$\begin{array}{c}\text { Anti- } \\
\text { serum }\end{array}$} & $\begin{array}{c}\text { Subgroup } \\
\text { I-1 }\end{array}$ & $\begin{array}{c}\text { Subgroup } \\
\text { I-2 }\end{array}$ & $\begin{array}{c}\text { Subgroup } \\
\text { I-3 }\end{array}$ & $\begin{array}{c}\text { Subgroup } \\
\text { I-4 }\end{array}$ \\
\hline I-1 & $1.00^{b}$ & 0.79 & 0.57 & 0.06 \\
I-2 & 0.89 & 1.00 & 0.79 & 0.14 \\
I-3 & 0.68 & 0.40 & 1.00 & 0.61 \\
I-4 & 0.09 & 0.00 & 0.17 & 1.00 \\
\hline
\end{tabular}

${ }^{a}$ Mean zone widths $\left(\bar{W}_{\mathrm{z}}\right)$ were calculated from the data in Table 2. Because the mean zone width was strongly influenced by spiroplasma growth rate, relative widths $\left(W_{r}\right)$ were calculated as follows: $W_{r}=\left(\dot{W}_{z}\right.$ for subgroup $s_{\mathbf{x}}$ antigen versus subgroup $s_{\mathbf{y}}$ antiserum)/ $\left(\bar{W}_{z}\right.$ for subgroup $s_{x}$ antigen versus subgroup $s_{x}$ antiserum). Boxhead $=s_{\mathbf{x}}$.

${ }^{b}$ Relative zone width.

tion and metabolism inhibition tests (55). Recent studies have provided further evidence for intergrading in the complex. For example, isolation of the LB-12 strain from the green leaf bug (27), isolation of the N525 strain from Cocos in Jamaica (19), and isolation of a cluster of flower strains (M52, M55, M58) from fall flowers in Maryland (52) have revealed the existence of other serovars that may be recognized as new subgroups. Discovery of new insect or flower strains could result in a myriad of subgroups or, even worse, the possible lack of any clear grouping (51). If further isolations continue to blur the distinctions among group I strains, the subgroup concept itself could be open to serious challenge. Extensive analyses of DNA-DNA homologies of some Acholeplasma species have shown that there is a broad cline of strains whose DNA-DNA homologies intergrade imperceptibly (G. S. Aulakh, E. B. Stephens, and M. F. Barile, personal communication) over a wide range. In a sense, such large clusters are reminiscent of "superspecies." S. citri may occupy a similar position.

Concepts of spiroplasma groupings $(17,55)$ have been formalized in two proposals. In one of these schemes (17), three serogroups and three subgroups were proposed and later supported by molecular genetic studies (26). A second proposal (25), based in part on serological groupings (55) and also on DNA-DNA hybridization data, analyses of guanine-plus-cytosine content, and two-dimensional electrophoresis data, defined five major groups and four subgroups. The latter scheme, because it is more inclusive in its analysis of divergent Spiroplasma strains and fully incorporates data on the genome, has now come into general acceptance. Our study demonstrates that the two spiroplasma groupings are consistent. Ten strains considered to represent the classical serovar of $\boldsymbol{S}$. citri (subgroup I-1 of
Junca et al. and subgroup I-A of Davis et al.) reacted similarly in their GI patterns. The BC-3 isolate of the honey bee spiroplasma $(10,55)$ reacted similarly to the AS $\mathbf{5 7 6}$ honey bee strain of Davis et al. (R. E. Davis, J. F. Worley, T. B. Clark, and M. Moseley, Proc. Am. Phytopathol. Soc. 3:304, 1976) and four other strains from bees and flowers. Thus, subgroup I-2 of Junca et al. and subgroup I-B of Davis et al. are homologous. Similarly, the I-747, E275, and Miss E strains form a cluster that represents subgroup I3 of Junca et al. and subgroup I-C of Davis et al. Neither subgroup I-4 (spiroplasma 277F) nor group II of Junca et al. (Drosophila sex ratio spiroplasma) was studied by Davis et al. Group III of Junca et al., represented by the OBMG and BNR1 strains, according to our GI tests, is similar or identical to the 23-6 strain designated (18) as the type strain of $S$. floricola (serogroup II of Davis et al.). A similar close relationship or identity is indicated between serogroup III of Davis et al. and group IV of Junca et al., since the SR 3 strain from flowers in Connecticut (15), the PPS1 strain from flowers in Florida (30), and five strains from flowers and insects in the Mediterranean region (L-89, B-13, F-1, F-2, and F-25) (50) appear to be closely related. However, analysis of this group (44) by metabolism inhibition has demonstrated considerable heterogeneity. Group V of Junca et al., representing $S$. mirum, was not studied by Davis et al. A recent report of a new spiroplasma from Ixodes pacificus ticks (45) established a candidate sixth major group, pending results from studies of its genome. Discovery of other spiroplasmas from arthropods (12) with diverse host relationships makes it certain that the grouping scheme will require frequent revisions and updates (2) to maintain its utility as a working system. Because classification in this grouping scheme requires not only serological data but also genomic data, provision has been made for establishment of provisional serogroups and serological subgroups (51). For example, the Ixodes spiroplasma has been designated as (VI).

Zones in nonspecific crosses were only rarely wider than 2 to $4 \mathrm{~mm}$. The factors that cause such zones are unclear. Such crosses, even though reproducible within batches of prepared disks, occurred only with certain combinations of strains and antisera. Of course, the occasional occurrence of nonspecific zones underscores the importance of using adequate controls and the value of examining several strains of any given organism in the assessment of its serological reactions.

A high general level of agreement between GI tests and other refined techniques for elucidation of spiroplasma interrelationships is evident. For example, results from molecular genetic 
(guanine-plus-cytosine determinations and DNA-DNA hybridization) and protein (two-dimensional polyacrylamide gel electrophoresis) analyses are in good accord with results obtained by GI tests. GI tests probably reflect affinity of antisera for membrane proteins (R. F. Whitcomb, J. G. Tully, and H. Wróblewski, in preparation). The membrane systems of spiroplasmas appear to be complex and, in the type species, involve at least 29 protein molecules, as resolved by one-dimensional polyacrylamide gel electrophoresis (59). This complexity forms a basis for a graded response between organisms that share some, but not nearly all, of their antigenic determinants. Other serological tests, such as the enzyme-linked immunosorbent assay $(1,9,38)$, may prove to be superior for elucidation of partial relationships. Particularly in comparison with the metabolism inhibition test (55), the GI test is relatively insensitive and does not dramatically reflect minor crossing. Probably for this reason the GI test in Mycoplas$m a$ and, apparently from our data, in Spiroplas$m a$, functions appropriately at the species level. The disk GI test is therefore an appropriate serological test in assessing the species taxonomy of new candidate Spiroplasma strains.

\section{REPRINT REQUESTS}

Address reprint requests to: $R$. F. Whitcomb, Insect Pathology Laboratory, Plant Protection Institute, Agricultural Research Service, U.S. Department of Agriculture, Beltsville, MD 20705.

\section{LITERATURE CITED}

1. Bové, J. M. 1980. Les spiroplasmes: nouveaux mycoplasmes pathogenes des vegetaux et des animaux, p. 379428. In C. R. Journ, Francaises sur les Maladies des Plantes. Association de Coordination Technique Agricole, Paris.

2. Bové, J. M. 1981. Mycoplasma infections of plants. Israel J. Med. Sci. 17:572-585.

3. Bové, J. M., and C. Saillard. 1979. Cell biology of spiroplasmas, p. 83-153. In R. F. Whitcomb and J. G. Tully (ed.), The mycoplasmas, vol. 3. Academic Press, Inc., New York.

4. Bové, J. M., C. Saillard, P. Junca, J. R. Degorce-Dumas, B. Ricard, A. Nhami, R. F. Whitcomb, D. Williamson, and J. G. Tully. 1982. Guanine plus cytosine content, hybridization percentages and EcoRI restriction enzyme profiles of spiroplasmal DNA. Rev. Infect. Dis. 4(Suppl.):S129\$138.

5. Brinton, L. P., and W. Burgdorfer. 1976. Cellular and subcellular organization of the $277 \mathrm{~F}$ agent, a spiroplasma from the rabbit tick Haemaphysalis leporispalustris (Acari: Ixodidae). Int. J. Syst. Bacteriol. 26:554-560.

6. Chen, T. A., and C. H. Liao. 1975. Corn stunt spiroplasma: isolation, cultivation, and proof of pathogenicity. Science 188:1015-1017.

7. Christiansen, C., G. Askaa, E. A. Freundt, and R. F. Whitcomb. 1979. Nucleic acid hybridization experiments with Spiroplasma citri and the corn stunt and suckling mouse cataract spiroplasmas. Curr. Microbiol. 2:323-336.

8. Christiansen, C., E. A. Freundt, and K. Maramorosch. 1980. Identity of cactus and lettuce spiroplasmas with Spiroplasma citri as determined by DNA-DNA hybridization. Curr. Microbiol. 4:353-356.

9. Clark, M. F., C. L. Flegg, M. Bar-Joseph, and S. Rottem.
1978. The detection of Spiroplasma citri by enzymelinked immunosorbent assay (ELISA). Phytopathol. Z. 92:332-337.

10. Clark, T. B. 1977. Spiroplasma sp., a new pathogen in honey bees. J. Invertebr. Pathol. 29:112-113.

11. Clark, T. B. 1978. Honey bee spiroplasmosis, a new problem for beekeepers. Am. Bee J. 118:18-19, 23.

12. Clark, T. B. 1982. Spiroplasmas: diversity of arthropod reservoirs and host-parasite relationships. Science 217:57-59.

13. Clyde, W. A. 1964. Mycoplasma species identification based upon growth inhibition by specific antisera. J. Immunol. 92:958-965.

14. Daniels, M. J., D. B. Archer, M. A. Stephens, R. Townsend, J. M. Longland, and J. Best. 1980. Comparison of spiroplasmas by polyacrylamide gel electrophoresis of cell proteins. Curr. Microbiol. 4:377-380.

15. Davis, R. E. 1978. Spiroplasma associated with flowers of the tulip tree (Liriodendron tulipifera L.). Can. J. Microbiol. 24:954-959.

16. Davis, R. E., and I. M. Lee. 1982. Comparative properties of spiroplasmas and emerging taxonomic concepts: a proposal. Rev. Infect. Dis. 4(Suppl):S122-S128.

17. Davis, R. E., I. M. Lee, and L. K. Basciano. 1979. Spiroplasmas: serological grouping of strains associated with plants and insects. Can. J. Microbiol. 25:861-866.

18. Davis, R. E., I. M. Lee, and J. F. Worley. 1981. Spiroplasma floricola, a new species isolated from surfaces of flowers of the tulip tree, Liriodendron tulipifera L. Int. J. Syst. Bacteriol. 31:456-464.

19. Eden-Green, S. J., and H. Waters. 1981. Isolation and preliminary characterization of a spiroplasma from coconut palms in Jamaica. J. Gen. Microbiol. 124:263-270.

20. Eden-Green, S. J., and H. Waters. 1981. Isolation of corn stunt spiroplasma in Jamaica, and probable dual infection with maize mosaic virus. Ann. Appl. Biol. 99:129-134.

21. Edward, D. G. f., and W. A. Fitzgerald. 1954. Inhibition of growth of pleuropneumonia-like organisms by antibody. J. Pathol. Bacteriol. 68:23-30.

22. Huijsman-Evers, A. G. M., and A. C. Ruys. 1956. Microorganisms of the pleuropneumonia group (family of $\mathrm{Myco}$ plasmataceae) in man. II. Serological identification and discussion of pathogenicity. Antonie van Leeuwenhoek J. Microbiol. Serol. 22:377-384.

23. Johnson, J. L. 1973. Use of nucleic acid homologies in the taxonomy of anaerobic bacteria. Int. J. Syst. Bacteriol. 23:308-315.

24. Jones, A. L., R. F. Whitcomb, D. L. Williamson, and M. E. Coan. 1977. Comparative growth and primary isolation of spiroplasmas in media based on insect tissue culture formulations. Phytopathology 67:738-746.

25. Junca, P., C. Saillard, J. Tully, O. Garcia-Jurado, J. R. Degorce-Dumas, C. Mouches, J. C. Vignault, R. Vogel, R. McCoy, R. Whitcomb, D. Williamson, J. Latrille, and J. M. Bové. 1980. Caractérisation de spiroplasmes isoles d'insectes et de fleurs de France continentale, de Corse et du Maroc: proposition pour une classification des spiroplasmes. C. R. Acad. Sci. Ser. D. 290:1209-1212.

26. Lee, I. M., and R. E. Davis. 1980. DNA homology among diverse spiroplasma strains representing several serological groups. Can. J. Microbiol. 26:1356-1363.

27. Lei, J. D., H. J. Su, and T. A. Chen. 1979. Spiroplasmas isolated from green leaf bug, Trigonotylus ruficornis Geoffroy, p. 89-97. In Proceedings of the R.O.C.-U.S. Cooperative Science Seminar, Mycoplasma Diseases of Plants. NSC Symposium Series, vol. 1. National Science Council, Taipei.

28. Liao, C. H., and T. A. Chen. 1981. Deoxyribonucleic acid hybridization between Spiroplasma citri and the corn stunt spiroplasma. Curr. Microbiol. 5:83-86.

29. Markham, P. G., R. Townsend, M. Bar-Joseph, M. J. Daniels, A. Plaskitt, and B. M. Meddins. 1974. Spiroplasmas are the causal agents of citrus little-leaf disease. Ann. Appl. Biol. 78:49-57.

30. McCoy, R. E., D. S. Williams, and D. L. Thomas. 1979. 
Isolation of mycoplasmas from flowers, p. 75-81. In Proceedings of the R.O.C.-U.S. Cooperative Science Seminar, Mycoplasma Diseases of Plants. NSC Symposium Series, vol. 1. National Science Council, Taipei.

31. Mouches, C., A. Menara, J. G. Tully, and J. M. Bové. 1982. Polyacrylamide gel analysis of spiroplasma proteins and its contribution to the taxonomy of spiroplasmas. Rev. Infect. Dis. 4(Suppl.):S141-147.

32. Mouches, C., J. C. Vignault, J. G. Tully, R. F. Whitcomb, and J. M. Bové. 1979. Characterization of spiroplasmas by one- and two-dimensional protein analysis on polyacrylamide slab gels. Curr. Microbiol. 2:69-74.

33. Nicol, C. S., and D. G. F. Edward. 1953. Role of organisms of the pleuropneumonia group in human genital infections. Br. J. Vener. Dis. 29:141-150.

34. Pickens, E. G., R. K. Gerloff, and W. Burgdorfer. 1968. Spirochete from the rabbit tick Haemaphysalis leporispalustris (Packard). J. Bacteriol. 95:291-299.

35. Rahimian, H., and D. J. Gumpf. 1980. Deoxyribonucleic acid relationship between Spiroplasma citri and the corn stunt spiroplasma. Int. J. Syst. Bacteriol. 30:605-608.

36. Raju, B. C., G. Nyland, T. Meikle, and A. H. Purcell. 1981. Helical, motile mycoplasmas associated with flowers and honey bees in California. Can. J. Microbiol. 27:249-253.

37. Saglio, P., M. L'Hospital, D. Lafleche, G. Dupont, J. M. Bové, J. G. Tully, and E. A. Freundt. 1973. Spiroplasma citri gen. and sp. n. A mycoplasma-like organism associated with "stubborn" disease of citrus. Int. J. Syst. Bacteriol. 23:191-204.

38. Saillard, C., J. Dunez, O. Garcia-Jurado, A. Nhami, and J. Bove. 1978. Detection de Spiroplasma citri dans les agrumes et les pervenches par la technique immunoenzymatique "ELISA." C. R. Acad. Sci. Ser. D 286:1245-1248.

39. Stalheim, O. H. V., A. E. Ritchie, and R. F. Whitcomb. 1978. Cultivation, serology, ultrastructure, and virus-like particles of spiroplasma 277F. Curr. Microbiol. 1:365-370.

40. Stanbridge, E., and L. Hayflick. 1967. Growth inhibition test for identification of mycoplasma species utilizing dried antiserum-impregnated paper discs. J. Bacteriol. 93:1392-1396.

41. Stiller, D., R. F. Whitcomb, M. E. Coan, and J. G. Tully. 1981. Direct isolation in cell-free medium of a spiroplasma from Haemaphysalis leporispalustris (Acari: Ixodidae) in Maryland. Curr. Microbiol. 5:339-342.

42. Subcommittee on the Taxonomy of Mollicutes. 1979. Proposal of minimal standards for descriptions of new species of the class Mollicutes. Int. J. Syst. Bacteriol. 29:172-180.

43. Subcommittee on the Taxonomy of Mycoplasmatales. 1977. Minutes of interim meeting, 22 September 1976. Int. J. Syst. Bacteriol. 27:392-394.

44. Tully, J. G., D. L. Rose, J. C. Vignault, C. Saillard, J. M. Bové, O. Garcia-Jurado, R. E. McCoy, and D. L. Willamson. 1980. Serological analysis of a new group of spiroplasmas. Curr. Microbiol. 3:369-372.

45. Tully, J. G., D. L. Rose, C. E. Yunker, J. Cory, R. F. Whitcomb, and D. L. Williamson. 1981. Helical mycoplasmas (spiroplasmas) from Ixodes ticks. Science 212:10431045.
46. Tully, J. G., R. F. Whitcomb, J. M. Bove, and P. Saglio. 1973. Plant mycoplasmas: serological relation between agents associated with citrus stubborn and corn stunt diseases. Science 182:827-829.

47. Tully, J. G., R. F. Whitcomb, H F. Clark, and D. L. Williamson. 1977. Pathogenic mycoplasmas: cultivation and vertebrate pathogenicity of a new spiroplasma. Science 195:892-894.

48. Tully, J. G., R. F. Whitcomb, D. L. Rose, and J. M. Bové 1982. Spiroplasma mirum, a new species from the rabbit tick (Haemaphysalis leporispalustris). Int. J. Syst. Bacteriol. 32:92-100.

49. Tully, J. G., R. F. Whitcomb, D. L. Williamson, and H F. Clark. 1976. Suckling mouse cataract agent is a helical wall-free prokaryote (spiroplasma) pathogenic for vertebrates. Nature (London) 259:117-120.

50. Vignault, J.-C., J. M. Bové, C. Saillard, R. Vogel, A. Farro, L. Venegas, W. Stemmer, S. Aoki, R. McCoy, A. S. Al-Beldri, M. Larue, O. Tuzcu, M. Ozsam, A. Nhami, M. Abassi, J. Bonfils, G. Moutous, F. Fos, A. Poutiers, and B. Viennot-Bourgin. 1980. Mise en culture de spiroplasmes à partir de matériel végétal et d'insectes provenant de pays circum-méditerranéens et du Proche-Orient. C. R. Acad. Sci. Ser. D 290:775-778.

51. Whitcomb, R. F., J. G. Tully, T. B. Clark, D. L. Williamson, and J. M. Bové. 1982. Revised serological classification of spiroplasmas, new provisional groups, and recommendations for serotyping of isolates. Curr. Microbiol. 7:291-296.

52. Whitcomb, R. F., J. G. Tully, D. L. Rose, E. B. Stephens, M. F. Barile, A. J. Smith, and R. E. MeCoy. Wall-less prokaryotes from fall flowers in central United States and Maryland. Curr. Microbiol. 7:285-290.

53. Whitcomb, R. F., and D. L. Williamson. 1975. Helical wall-free prokaryotes in insects: multiplication and pathogenicity. Ann. N.Y. Acad. Sci. 266:260-275.

54. Williamson, D. L. 1982 . Serological characterization of spiroplasmas and other mycoplasmas, p. 240-267. In M. J. Daniels and P. G. Markham (ed.), Practical techniques for the study of plant and insect mycoplasmas. Croom Helm Ltd., London.

55. Williamson, D. L., J. G. Tully, and R. F. Whitcomb. 1979. Serological relationships of spiroplasmas as shown by combined deformation and metabolism inhibition tests. Int. J. Syst. Bacteriol. 29:345-351.

56. Williamson, D. L., and R. F. Whitcomb. 1975. Plant mycoplasmas: a cultivable spiroplasma causes corn stunt disease. Science 188:1018-1020.

57. Williamson, D. L., R. F. Whitcomb, and J. G. Tully. 1978. The deformation test, a new serological method. Curr. Microbiol. 1:203-207.

58. Working Group of the FAO/WHO Programme on Comparative Mycoplasmology. 1976. The growth inhibition test. World Health Organization Working Document VPH/ MIC/76.7. World Health Organization, Geneva.

59. Wroblewski, H., R. Burlot, and D. Thomas. 1981. Adsorption of proteins from the Spiroplasma citri cell membrane by magnesium lauroyl-sarcosinate crystals. Biochimie 63:177-186. 